\title{
MANAJEMEN LABORATORIUM HANGGAR PESAWAT
}

\author{
Nanyka Dyah Wijayanti \\ SD Kartika 47 Malang, Jalan Ksatrian 1A Malang \\ E-mail : nanyka.dyah@gmail.com
}

\begin{abstract}
The main objective of this research was to describe the management of plane hangar laboratory. The research method used qualitative approach and design of research case study. The technique of data collection techniques interviews, observation and documentation. Checking the validity of the data using triangular and use of reference materials. The results of the management of laboratory practice activities plane hangar learners in hangars will run effectively.
\end{abstract}

Keywords : management, facilities and infrastructure, management services, laboratories.

\begin{abstract}
Abstrak : Tujuan utama dari penelitian ini adalah untuk mendeskripsikan manajemen laboratorium hanggar pesawat. Metode penelitian yang digunakan yaitu pendekatan kualitatif dan rancangan penelitian yaitu studi kasus. Teknik pengumpulan data menggunakan teknik wawancara, observasi dan dokumentasi. Pengecekan keabsahan data menggunakan trianggulasi dan menggunakan bahan referensi. Hasil dari manajemen laboratorium hanggar pesawat yaitu kegiatan praktik peserta didik di hanggar pesawat akan berjalan secara efektif.
\end{abstract}

Kata Kunci : manajemen, sarana dan prasarana, manajemen layanan khusus, laboratorium.

Pendidikan merupakan hal terpenting dalam kehidupan seseorang (Gunawan, 2008; Gunawan, 2011). Melalui pendidikan, seseorang dapat mengembangkan potensinya, memiliki karir yang baik serta dapat bertingkah sesuai norma-norma yang berlaku. Pendidikan adalah usaha sadar dan terencana secara etis, sistematis, intensional dan kreatif dimana peserta didik mengembangkan potensi diri, kecerdasan, pengendalian diri dan keterampilan untuk membuat dirinya berguna di masyarakat. Keberhasilan program pendidikan melalui proses pembelajaran di sekolah sangat dipengaruhi oleh banyak faktor, salah satu diantaranya adalah tersedianya sarana dan prasarana pendidikan yang memadai disertai pengelolaannya secara optimal (Gunawan, 2017). Sarana dan prasarana pendidikan merupakan salah satu sumberdaya yang penting dan utama dalam menunjang proses pembelajaran di sekolah.

Sarana pendidikan adalah peralatan dan perlengkapan yang secara langsung dipergunakan dan menunjang proses pendidikan, khususnya proses belajar mengajar, seperti gedung, ruang kelas, meja, kursi, serta alat-alat dan media pen- gajaran (Mulyasa, 2007; Gunawan dan Benty, 2017). Sedangkan prasarana pendidikan adalah fasilitas yang secara tidak langsung menunjang jalannya proses pendidikan atau pengajaran, seperti halaman, kebun, taman, jalan, tetapi jika dimafaatkan secara langsung untuk proses belajar dan proses mengajar, seperti taman untuk pengajaran biologi, halaman sekolah sekaligus lapangan olahraga, komponen tersebut merupakan sarana pendidikan (Mulyasa, 2007; Gunawan dan Benty, 2017). Sergiovani menyatakan manajemen merupakan proses pendayagunaan semua sumber daya dalam rangka mencapai tujuan yang telah ditetapkan (Bafadal, 2008). Pendayagunaan melalui tahapan proses yang meliputi pe-rencanaan, pengorganisasian, pelaksanaan, dan pengawasan. Dengan manajemen yang efektif dan efisien diharapkan dapat meningkatkan efektivitas dan efisiensi kerja personil sekolah (Gunawan, 2017a; Gunawan, 2017b). Manajemen sarana dan prasarana sekolah dapat didefinisikan sebagai proses kerjasama pendayagunaan semua perlengkapan pendidikan secara efektif dan efisien untuk mencapai tujuan pendidikan (Gunawan dan Benty, 2017). 
SMK Penerbangan Angkasa merupakan salah satu sekolah yang bergerak di bidang kompetensi pesawat terbang, baik pesawat terbang penumpang maupun pesawat terbang militer. Sekolah ini mempunyai dua jurusan yang dapat dipilih yaitu: AFP (Air Frame \& Power Plant) dan AEI (Avionic Electric Instrument). Beberapa fasilitas yang dimiliki sekolah yaitu hanggar pesawat terbang (AFP dan AEI), Laboratorium Komputer, Laboratorium Bahasa, Laboratorium Gambar, Kantin, Musholla, Koperasi Siswa, Ruang Multimedia, Sanggar Pramuka, Lapangan Olahraga, Perpustakaan. Sekolah ini merupakan satu-satunya sekolah penerbangan yang berada di Malang Raya sehingga peminat dari sekolah ini cukup banyak. Banyaknya calon peserta didik yang berminat untuk bersekolah disini maka sekolah membutuhkan sarana dan prasarana yang lengkap untuk menunjang pembelajaran, terutama yaitu laboratorium atau bengkel kerja yang utamanya untuk menunjang keahlian para peserta didik. Laboratorium atau bengkel kerja merupakan hal yang paling utama atau inti dari sekolah kejuruhan yang berorientasi kepada kemampuan atau keahlian peserta didik untuk menghadapi dunia kerja.

Peneliti ini fokus pada hanggar pesawat yang saat proses belajar mengajar memiliki berbagai kegunaan yaitu selain sebagai tempat praktik, juga sebagai tempat ujian. Imron (2004) menyatakan laboratorium adalah suatu tempat baik tertutup maupun terbuka yang dipergunakan untuk melakukan penyelidikan, percobaan, pemratikkan, pengujian, dan pengembangan. Sedangkan menurut Wiyono (1999) bengkel kerja merupakan instalasi sekolah yang memberikan layanan di bidang fasilitas ruang, perlengkapan dan peralatan untuk melakukan kerja praktik dalam bidang studi tertentu sesuai dengan tingkat dan jenis sekolah yang bersangkutan. Bentuk bengkel kerja bermacam-macam, antara lain bengkel mesin dan bengkel listrik untuk SMK/ STM, bengkel seni untuk sekolah seni rupa, bengkel karawitan untuk sekolah karawitan, bengkel percetakan untuk sekolah menengah teknologi grafika, dan bengkel memasak untuk sekolah kesejahteraan keluarga. Untuk setiap jenis sekolah dapat mempunyai lebih dari satu macam bengkel, tergantung pada kebutuhannya dalam menunjang kurikulum yang bersangkutan.

\section{METODE}

Penelitian ini menggunakan pendekatan kualitatif dengan rancangan studi kasus. Lokasi penelitian ini adalah di SMK Penerbangan Angkasa di Singosari Malang. Pengumpulan data dalam penelitian ini menggunakan teknik wawancara, observasi dan dokumentasi. Sumber data dalam penelitian ini: key informan pada penelitian ini yaitu Kepala Program Studi (Kepala Program Studi AEI dan Kepala Program Studi AFP) sedangkan informan pada penelitian ini yaitu Waka Kurikulum, Waka Sarana dan Prasarana, Waka Humas, guru pengajar, dan siswa. Pengecekan keabsahan data dilakukan menggunakan trianggulasi dan menggunakan bahan referensi (Gunawan, 2014).

\section{HASIL}

\section{Proses Penyusunan Program Laboratorium Hanggar Pesawat}

Proses penyusunan program laboratorium hanggar pesawat di SMK Penerbangan Angkasa Singosari Malang dimulai dari pembentukan kepanitiaan kemudian tim kecil yang terbagi menjadi guru produktif, adaptif dan normatif. Sesudah dibentuk kepanitiaan maka sekolah mengadakan workshop, workhop tersebut dihadiri oleh kepala sekolah, wakil kepala sekolah, kaprodi, dan seluruh dewan guru. Workshop tersebut membahas evaluasi program tahun sebelumnya dan setelah evaluasi selesai maka dibuat rancangan untuk program satu tahun kedepan.

Program yang sudah selesai maka akan divalidasi dengan mengundang pengawas sekolah untuk diperbaiki jika ada yang kurang atau perlu ditambahi, setelah program divalidasi maka sekolah akan mensosialisasikan kepada seluruh dewan guru dan Kaprodi. Dalam penyusunan program di SMK Penerbangan Angkasa terdapat beberapa acuan/landasan yaitu Undang-undang Nomor 20 Tahun 2003 tentang Sistem Pendidikan Nasional dan peraturan menteri yang terkait 8 standar pendidikan, dan jika di dalam penyusunan program ada pro dan kontra maka sekolah melakukan musyawarah mufakat, sekolah mengambil musyawarah mufakat untuk mengambil yang terbaik dengan catatan jika masih terjadi perbedaan sekolah meminta penengah yaitu dari pengawas sekolah. 


\section{Pengorganisasian Laboratorium Hanggar Pesawat}

Laboratorium hanggar pesawat di SMK Penerbangan Angkasa Singosari Malang ditata oleh kaprodi AEI dan AFP. Pengorganisasian di hanggar pesawat meliputi struktur organisasi dan pembagian tugas tiap-tiap personel di hanggar pesawat. Struktur organisasi hanggar pesawat SMK Penerbangan Angkasa yaitu hanggar pesawat AEI strukturnya meliputi kepala sekolah, kepala program AEI, sekretaris, bendahara dan kabengkel (Kabengkel Instrument, Kabengkel Listrik, Kabengkel Avionic). Sedangkan untuk Jurusan AFP strukturnya yaitu kepala sekolah, kepala program AFP, sekretaris, bendahara dan kabengkel (Kabengkel Sifmetal \& Repair, Kabengel Hydrolic, Kabengkel Wearding, Kabengkel Engine). Pembagian tugas sesuai dengan bidang yang dikuasai, sedangkan untuk Penugasan/ penunjukan personel khusus produktif minimal sudah mempunyai kualifikasi inspektor atau supervisor. Kalau yang produktif di hanggar pesawat bisa tidak mempunyai gelar tetapi harus minimal sudah mempunyai pengalaman kerja di dunia penerbangan selama 5 tahun dan atau yang sudah mempunyai kualifikasi inspektor.

\section{Penggunaan Laboratorium Hanggar Pesawat}

Penggunaan laboratorium hanggar pesawat di SMK Penerbangan Angkasa Singosari Malang disesuaikan dengan jadwal yang telah ditentukan oleh sekolah. Terdapat prosedur dan tata tertib yang harus dipatuhi di dalam hanggar pesawat, Apabila tata tertib dilanggar maka ada sanksi/ hukuman yang akan diberikan kepada siswa yaitu yang pertama diingatkan, yang kedua bila dengan diingatkan tetap melanggar maka diberi peringatan, jika mengulangi lagi maka peserta didik diberikan tindakan, tindakan ini bukan tindakan kekerasan/memukul melainkan dengan nasihat jadi sifatnya itu membina seperti push up untuk laki-laki dan perempuan yaitu engklek dan keliling hanggar. Prosedur penggunaan hanggar pesawat yaitu harus safety first/keselamatan kerja harus diutamakan dengan menggunakan pakaian kerja dan alat pelindung kerja, sedangkan tata tertib di dalam hanggar pesawat ada 3 tata tertib yang harus dipatuhi oleh para peserta didik yaitu tata tertib di ruang praktik, tata tertib peminjaman tools, tata tertib pengembalian tools.

\section{Pemeliharaan Laboratorium Hanggar Pesawat}

Pemeliharaan hanggar pesawat melibatkan semua warga sekolah, tidak ada orang khusus untuk memelihara hanggar pesawat. Pemeliharaan hanggar pesawat di SMK Penerbangan ada pemeliharaan bersifat perbaikan berat, pemeliharaan bersifat perbaikan ringan, pemeliharaan berkala dan pemeliharaan sehari-hari. Pemeliharaan ringan contohnya seperti kerusakan lampu maka guru dan siswa yang memperbaiki. Perbaikan berat, seperti perbaikan gedung maka sekolah dan yayasan yang mengurus pemeliharaan itu. Pemeliharaan sehari-hari dihanggar pesawat seperti sebelum bekerja menyapu, mengelap, memberi oli untuk maintenance alat-alat, terus menyimpan alat setelah dipakai harus dikasih oli dulu baru disimpan, kemudian menaruh peralatan kunci-kunci pada toolbox. Pemeliharaan berkala biasanya 6 bulan sekali contohnya seperti komponen-kompenen yang tidak bisa dipakai dikumpulkan dan diganti dengan yang baru, kemudian juga ada pengecetan ruangan secara berkala. Sumber dana untuk pemeliharaan hanggar pesawat yaitu dari yayasan dan dinas pendidikan.

\section{Pengawasan Laboratorium Hanggar Pesawat}

Pengawasan di laboratorium hanggar pesawat dilakukan oleh kaprodi AEI dan AFP. Aspek yang diawasi oleh kepala program yaitu kinerja para guru dan kegiatan siswa di dalam hanggar pesawat, jadi kepala program mengawasi juga mengarahkan sejauh mana guru jangan sampai over light jadi harus sesuai dengan kurikulum yang ada. Teknik yang dilakukan di dalam hanggar pesawat SMK Penerbangan Angkasa yaitu ada pengawasan langsung dan tidak langsung. Pengawasan langsung seperti Kaprodi mengarahkan guru apabila terjadi over light maka kaprodi membimbing / mengarahkan langsung kepada guru yang bersangkutan. Sedangkan teknik tidak langsung yaitu dilihat dari job sheet/laporan kinerja tiap-tiap guru di hanggar pesawat, dikarenakan setelah melakukan kegiatan guru juga membuat laporan hasil kegiatan selama di hanggar. 


\section{Masalah-Masalah dan Solusi dalam Pengimplementasian Laboratorium Hanggar Pesawat}

Permasalahan di dalam pengimplementasian hanggar pesawat yaitu masalah waktu, masalah gedung yang belum memenuhi kriteria, masalah pendanaan untuk sarana dan prasarana, dan masalah arus listrik. Permasalahan waktu untuk pengajar produktif mempunyai masalah dalam membagi waktu antara waktu dinas dengan waktu mengajar, dikarenakan untuk mengajar mencari waktu yang longgar. Solusi untuk mengatasi permasalahan tersebut yaitu melakukan koordinasi dengan waka kurikulum hari apa saja waktu luang untuk guru pengajar di hanggar pesawat.Permasalahan dana untuk perbaikan hanggar pesawat, dikarenakan untuk menyesuaikan hanggar biar sesuai dengan kriteria itu terkendala oleh dana karena dananya terbatas sedangkan untuk perbaikan hanggar perlu dana yang besar.

Sekolah tidak mungkin menggunakan dana dari yayasan dikarenakan juga masih belum mencukupi, jadi sekolah mengandalkan dari bantuan pemerintah untuk perbaikan hanggar pesawat. Solusi untuk permasalahan ini yaitu membuat proposal dan mengajukan kepada yayasan/diknas untuk perbaikan hanggar pesawat.Permasalahan pesawat yaitu harus ada pesawat dan komponen pesawat beli diluar juga tidak ada. Jadi bagaimanapun harus ada barang dari pesawat. Solusinya yaitu mengajukan kepada yayasan untuk pengadaan komponen di hanggar pesawat. Permasalahan Arus yaitu apabila mati lampu otomatis siswa tidak bisa bekerja, karena tidak ada arus jadi siswa harus belajar alat secara manual.

\section{PEMBAHASAN}

\section{Proses Penyusunan Program Laboratorium Hanggar Pesawat}

Penyusunan program adalah proses pembuatan keputusan mengenai program-program yang akan dilaksanakan oleh suatu organisasi dan taksiran jumlah sumber-sumber yang akan dialokasikan untuk setiap program tersebut. Hasil temuan peneliti mengenai proses penyusunan program laboratorium hanggar pesawat di SMK Penerbangan Angkasa Malang adalah di dalam penyusunan program di SMK Penerbangan Angkasa terdapat beberapa acuan yaitu hasil evaluasi program kerja tahun lalu, peraturan sisdiknas Nomer 20 Tahun 2003 dan peraturan menteri yang terkait 8 standart pendidikan. Hal ini sesuai dengan pendapat dari Gunawan dan Benty (2017) terdapat beberapa landasan yang menjadi dasar dari pelaksanaan program kerja di suatu sekolah, yaitu: (1) Undang-undang Nomor 20 Tahun 2003 tentang Sistem Pendidikan Nasional pasal 4 tentang pengelolaan dana pendidikan berdasar pada prinsip keadilan, efesiensi, transparansi dan akuntabilitas publik; (2) Undang-undang Nomor 25 Tahun 2004 tentang Sistem Perencanaan Pembangunan Nasional; (3) Peraturan Pemerintah Nomor 19 Tahun 2005 tentang Standar Nasional Pendidikan pasal 53 yang menyatakan setiap satuan pendidikan dikelola atas dasar rencana kerja tahunan yang merupakan penjabaran rinci dari rencana kerja jangka menengah satuan pendidikan yang meliputi masa 4 tahun); dan (4) Permendiknas Nomor 19 Tahun 2007 tentang Standar Pengelolaan Pendidikan.

Sekolah membuat Rencana Kerja Jangka Menengah (RKJM) 4 tahun, Rencana Kerja Tahunan (RKT) dinyatakan dalam Rencana Kegiatan dan Anggaran Sekolah / Madrasah (RKAS/M) dilaksanakan berdasarkan RKJM. RKJM/T disetujui rapat dewan pendidik setelah memperhatikan pertimbangan dari Komite Sekolah dan disahkan berlakunya oleh Dinas Pendidikan Kab/Kota. Langkah-langkah yang dilakukan dalam penyusunan program di SMK Penerbangan Angkasa yaitu sekolah melakukan evaluasi diri IDS di program tahun sebelumnya. Setelah IDS terbentuk baru menjadi acuan sebagai rencana kerja/program untuk tahun berikutnya. Setelah rencana kerja/program itu jadi sekolah melakukan validasi dengan mengundang narasumber yaitu pengawas sekolah. Sebagai bentuk laporan jika ada yg kurang atau perlu ditambahi. Hal ini sesuai dengan pendapat Rahmah (2013) langkah-langkah yang dapat digunakan dalam merencanakan programprogram kerja sekolah yaitu: (1) pengumpulan data; (2) analisis data; (3) strategi dan penentuan; (4) media / sarana pelaksanaan; dan (5) evaluasi. 


\section{Pengorganisasian Laboratorium Hanggar Pesawat}

Kegiatan pengorganisasian di SMK Penerbangan Angkasa Singosari berupa pembagian tugas dan wewenang, tanggung jawab yang terkait dalam suatu organisasi sesuai dengan bidangnya masing-masing. Berdasarkan temuan peneliti mengenai pengorganisasian di SMK Penerbangan Angkasa Singosari Malang yaitu untuk pembagian tugas diserahkan kepada kaprodi tiaptiap jurusan dan untuk penugasan/penunjukan personel hanggar pesawat disesuaikan pada bidang yang dikuasai dan setiap personel produktif di hanggar pesawat harus minimal sudah mempunyai kualifikasi sebagai inspektor/supervisor dan mempunyai pengalaman kerja di dunia pe-nerbangan selama 5 tahun. Hal ini sesuai dengan pendapat Siagian yang menyatakan bahwa pengorganisasian sebagai keseluruhan proses pengelompokan orang-orang, alat-alat, tugastugas, tanggung jawab sedemikian rupa sehingga tercipta organisasi yang dapat digerakkan sebagai kesatuan dalam rangka pencapaian tujuan yang telah ditentukan (Mustiningsih, 2005).

\section{Penggunaan Laboratorium Hanggar Pesawat}

Penggunaan dapat dikatakan sebagai kegiatan pemanfaatan sarana dan prasarana pendidikan untuk mendukung proses pendidikan demi mencapai tujuan pendidikan. Berdasarkan temuan peneliti mengenai penggunaan laboratorium hanggar pesawat yaitu penggunaan hanggar pesawat disesuaikan dengan jadwal penggunaan hanggar pesawat yang telah ditentukan sebelumnya, dalam penggunaan hanggar pesawat terdapat prosedur dan tata tertib yang harus dipatuhi, jika tata tertib dilanggar maka akan ada sanksi/hukuman yang akan diterima oleh yang melanggar. Prosedur penggunaan hanggar pesawat yaitu harus safety first/keselamatan kerja harus diutamakan, para peserta didik diwajibkan menggunakan pakaian kerja dan menggunakan alat pelindung kerja untuk keamanan para peserta didik sendiri.

Sedangkan untuk tata tertib yang harus dipatuhi saat di hanggar pesawat yaitu tata tertib di ruang praktik, tata tertib peminjaman peralatan, tata tertib pengembalian peralatan. Apabila tata tertib dilanggar maka para siswa akan diberikan sanksi, sanksi tersebut sesuai dengan kriteria kesalahan yang dilakukan siswa. Sanksi disini bukan berupa kekerasan tetapi bersifat membina/motivasi. Hal ini sesuai dengan pendapat Herawan dan Nasihin yang menyatakan bahwa dalam penggunaan sarana dan prasarana ada beberapa hal yang perlu diperhatikan yaitu: (1) penyusunan jadwal penggunaan harus dihindari benturan dengan kelompok lainnya; (2) hendaknya kegiatan-kegiatan pokok sekolah merupakan prioritas pertama; (3) waktu/jadwal penggunaan hendaknya diajukan pada awal tahun ajaran; (4) penugasan/penunjukan personel sesuai dengan keahlian pada bidangnya, misalnya petugas laboratorium, perpustakaan, operator komputer, dan sebagainya; dan (5) penjadwalan dalam penggunaan sarana dan prasarana sekolah, antara kegiatan intrakurikuler dengan ekstrakurikuler harus jelas (Barnawi dan Arifin, 2012).

\section{Pemeliharaan Laboratorium Hanggar Pesawat}

Kegiatan pemeliharaan laboratorium hanggar pesawat di SMK Penerbangan Angkasa Singosari Malang berupa pemeliharaan bersifat perbaikan ringan, pemeliharaan bersifat perbaikan berat, pemeliharaan sehari-hari, pemeliharaan berkala. Pemeliharaan sarana dan prasarana pendidikan adalah kegiatan untuk melaksanakan pengurusan dan pengaturan agar semua sarana dan prasarana selalu dalam keadaan baik dan siap untuk digunakan secara berdaya guna dan berhasil guna dalam mencapai tujuan pendidikan. Berdasarkan temuan peneliti mengenai pemeliharaan laboratorium hanggar pesawat yaitu pemeliharaan perbaikan ringan contohnya seperti kerusakan lampu maka guru dan siswa yang memperbaiki sedangkan perbaikan berat seperti perbaikan gedung maka sekolah dan yayasan yang mengurus pemeliharaanseperti itu. Pemeliharaan sehari-hari dihanggar pesawat seperti sebelum peserta didik bekerja di hanggar maka peserta didik diharuskan menyapu, mengelap, memberi oli untuk maintenance alatalat, terus menyimpan alat setelah dipakai harus dikasih oli dulu baru disimpan, kemudian menaruh peralatan kunci-kunci pada toolbox.

Pemeliharaan berkala biasanya 6 bulan sekali contohnya seperti komponen-kompenen yang tidak bisa dipakai dikumpulkan dan diganti dengan yang baru, kemudian juga ada pengecetan 
ruangan secara berkala. Hal ini sesuai dengan pendapat Bafadal (2008) bahwa pemeliharaan dapat ditinjau dari sifatnya dan waktu pemeliharaannya. Ditinjau dari sifatnya ada empat macam pemeliharaan sarana dan prasarana pendidikan di sekolah. Keempat macam pemeliharaan tersebut cocok untuk perawatan mesin. Berikut ini macam pemeliharaan berdasarkan sifatnya yaitu: (1) pemeliharaan perlengkapan yang bersifat pengecekan, (2) pemeliharaan yang bersifat pencegahan, (3) pemeliharaan yang bersifat perbaikan ringan, dan (4) perbaikan berat. Sedangkan ditinjau dari waktu pemeliharaan ada dua macam pemeliharaan sarana dan prasarana pendidikan di sekolah. berikut ini macam pemeliharaan berdasarkan waktunya yaitu: (1) pemeliharaan sehari-hari; dan (2) pemeliharaan berkala.

\section{Pengawasan Laboratorium Hanggar Pesawat}

Pengawasan atau evaluasi dimaksudkan untuk mengetahui bahwa hasil pelaksanaan pekerjaan sedapat mungkin sesuai dengan rencana. Hal ini membandingkan antara kenyataan dengan standar yang telah ditentukan semula. Bila perlu, mengadakan pembetulan atau perbaikan apabila ternyata dalam pelaksanaan terdapat adanya penyimpangan dari rencana. Berdasarkan temuan peneliti pengawasan laboratoium hanggar pesawat di SMK Penerbangan Angkasa Singosari Malang dilakukan oleh kaprodi selaku pengelola manajemen di hanggar pesawat. Aspek yang diawasi yaitu kinerja guru, jadi Kaprodi mengawasi bagaimana ketika guru mengajar/melakukan kegiatan di hanggar pesawat apakah sudah sesuai dengan kurikulum yang ada.

Jika ada yang menyimpang, maka Kaprodi akan menasehati ataupun membimbing guru tersebut agar sesuai dengan kurikulum yang ada. Hal ini sesuai dengan pendapat Kombrough dan Pengawasan sebagai proses memonitor kegiatankegiatan, tujuannya adalah untuk menentukan harapan-harapan yang secara nyata dicapai dan melakukan perbaikan-perbaikan terhadap penyimpangan-penyimpangan yang terjadi, yang dimaksud dengan harapan-harapan disini adalah tujuan-tujuan yang telah ditentukan untuk dicapai dan program-program yang telah direncanakan sebelumnya (Tim Pakar Manajemen Pendidikan, 2002; Gunawan, 2016).

\section{Masalah-masalah dan Solusi dalam Pengimplementasian Laboratorium}

Masalah yaitu suatu hambatan atau kendala dalam mencapai tujuan yang telah direncanakan. Berdasarkantemuan penelitimasalah-masalahdan solusi dalam pengimplementasian laboratorium hanggar pesawat di SMK Penerbangan Angkasa Singosari Malang yaitu ruangan hanggar pesawat yang belum memenuhi standar, permasalahan waktu untuk pengajar produktif, permasalahan dana, permasalahan pesawat, permasalahan arus, dari berbagai permasalahan tersebut ada beberapa solusi yang dapat digunakan yaitu merenovasi hanggar pesawat agar sesuai standart, melakukan koordinasi dengan waka kurikulum hari apa saja waktu luang untuk guru pengajar di hanggar pesawat, membuat proposal dan mengajukan kepada Yayasan atau Dinas Pendidikan untuk perbaikan hanggar pesawat, mengajukan kepada yayasan untuk pengadaan komponen di hanggar pesawat, peserta didik belajar alat secara manual. Hal ini sesuai dengan pendapat Rosa (2014) bahwa faktor penghambat pelaksanaan praktikum di laboratorium yaitu kurang sarana dan prasarana, pengelolaan laboratorium yang kurang baik, dan kurangnya waktu yang tersedia.

\section{KESIMPULAN DAN SARAN}

\section{Kesimpulan}

Manajemen laboratorium hanggar pesawat di SMK Penerbangan Angkasa Singosari Malang meliputi: (1) proses penyusunan program laboratorium hanggar pesawat; (2) pengorganisasian laboratorium hanggar pesawat; (3) penggunaan laboratorium hanggar pesawat; (4) pemeliharaan laboratorium hanggar pesawat; (5) pengawasan laboratorium hanggar pesawat; dan (6) masalahmasalah dan solusi dalam pengimplementasian laboratorium hanggar pesawat. Proses penyusunan program laboratorium hanggar pesawat di SMK Penerbangan Angkasa Singosari Malang dimulai dari pembentukan kepanitiaan kemudian tim kecil yang terbagi menjadi guru produktif, adaptif dan normatif. Sesudah dibentuk kepanitiaan maka sekolah mengadakan workshop, workhop tersebut dihadiri oleh kepala sekolah, wakil kepala sekolah, kaprodi, dan seluruh dewan guru. Workshop tersebut membahas evaluasi program tahun sebelumnya dan setelah evaluasi 
selesai maka dibuat rancangan untuk program satu tahun kedepan.

Program yang sudah selesai maka akan divalidasi dengan mengundang pengawas sekolah untuk diperbaiki jika ada yang kurang atau perlu ditambahi, setelah program divaidasi maka sekolah akan mensosialisasikan kepada seluruh dewan guru dan kaprodi. Laboratorium hanggar pesawat di SMK Penerbangan Angkasa Singosari Malang dikelola oleh kaprodi AEI dan AFP. Pengorganisasian di hanggar pesawat meliputi struktur organisasi dan pembagian tugas tiap-tiap personel di hanggar pesawat. Pembagian tugas sesuai dengan bidang yang dikuasai, sedangkan untuk kualifikasi guru pengajar khusus produktif mayoritas sudah mempunyai kualifikasi inspektor/supervisor dan mempunyai pengalaman kerja di dunia penerbangan selama 5 tahun. Penggunaan laboratorium hanggar pesawat di SMK Penerbangan Angkasa Singosari Malang disesuaikan dengan jadwal yang telah ditentukan oleh sekolah.

Terdapat prosedur dan tata tertib yang harus dipatuhi di dalam hanggar pesawat, apabila prosedur dan tata tertb itu dilanggar maka akan mendapat sanksi/hukuman sesuai dengan kriteria kesalahannya. Prosedur penggunaan hanggar pesawat yaitu harus safety first/keselamatan kerja harus diutamakan dengan menggunakan pakaian kerja dan alat pelindung kerja, sedangkan tata tertib di dalam hanggar pesawat ada 3 tata tertib yang harus dipatuhi oleh para peserta didik yaitu tata tertib di ruang praktik, tata tertib peminjaman tools, tata tertib pengembalian tools. Pemeliharaan hanggar pesawat melibatkan semua warga sekolah, tidak ada orang khusus untuk memelihara hanggar pesawat. Pemeliharaan hanggar pesawat di SMK Penerbangan ada pemeliharaan bersifat perbaikan berat, pemeliharaan bersifat perbaikan ringan, pemeliharaan berkala dan pemeliharaan sehari-hari. Sumber dana untuk pemeliharaan hanggar pesawat yaitu dari yayasan dan diknas.

Pengawasan di laboratorium hanggar pesawat dilakukan oleh kaprodi AEI dan AFP. Aspek yang diawasi yaitu kinerja guru, adapun teknik pengawasan yang digunakan dalam pengawasan laboratorium hanggar pesawat yaitu pengawasan tidak langsung dan pengawasan langsung. Pengawasan tidak langsung dilihat dari job sheet keseharian guru, sedangkan pengawasan langsung dilihat dari kegiatan sehari-hari guru. Permasalahan di dalam pengimplementasian hanggar pesawat yaitu masalah waktu, masalah gedung yang belum memenuhi kriteria, masalah pendanaan untuk sarana dan prasarana, dan masalah arus listrik. Sedangkan solusinya yaitu membuat proposal kemudian mengajukan kepada yayasan maupun dinas pendidikan, berkoordinasi dengan waka kurikulum hari apa saja waktu luang untuk guru pengajar di hanggar pesawat.

\section{Saran}

Berdasarkan hasil penelitian, saran yang diajukan adalah bagi Yayasan SMK Penerbangan diharapkan senantiasa berkoordinasi dengan pihak sekolah untuk pengadaan komponen pesawat yang dibutuhkan oleh sekolah. Bagi Kepala Sekolah hendaknya dapat ikut serta di dalam hanggar pesawat, ikut serta dalam pengelolaan maupun pembelajaran di hanggar pesawat. Bagi Guru hendaknya mempertahankan kreativitas dalam pembelajaran agar pembelajaran berjalan sesuai yang telah ditentukan. Bagi Tim/Staf Laboratorium hendaknya dapat senantiasa berkoordinasi dengan kaprodi dalam hal pengelolaan hanggar pesawat. Bagi Peneliti Lain diharapkan melakukan penelitian terutama tentang budaya pembelajaran berbasis militer di SMK Penerbangan Angkasa Singosari Malang.

\section{DAFTAR RUJUKAN}

Bafadal, I. 2008. Manajemen Perlengkapan Sekolah. Jakarta: Bumi Aksara.

Barnawi dan Arifin, M. 2012. Manajemen Sarana dan Prasarana Sekolah. Jogjakarta: AR-Ruzz Media.

Gunawan, I. 2008. Pendidikan Perdamaian. Banjarmasin Pos, 24 Desember, hlm. 6.

Gunawan, I. 2011. Merekonstruksi Fitrah Pendidikan. Komunikasi, Majalah Kampus Universitas Negeri Malang, Tahun 33 Nomor 276 September - Oktober 2011, hlm. 32

Gunawan, I. 2014. Metode Penelitian Kualitatif: Teori dan Praktik. Jakarta: PT Bumi Aksara.

Gunawan, I. 2016. Pasaran: Menggali Nilai-nilai Permainan Tradisional dalam Mengembangkan Sifat-sifat Kepemimpinan Pendidikan. Jurnal Studi Sosial, 8(1), 55-64.

Gunawan, I. 2017a. Instructional Management in Indonesia: A Case Study. Journal of Arts, Science and Commerce, 8(1), 99-107. 
Gunawan, I. 2017b. Instructional Leadership Profile of Junior High School's Principal (A Case Study of Junior High School in Malang). International Research-Based Education Journal, 1(1), 64-68.

Gunawan, I. 2017c. Penerapan Manajemen Pembelajaran Berbasis Lesson Study dan Dampaknya terhadap Keaktifan Mahasiswa dalam Perkuliahan. Jurnal Pendidikan dan Pembelajaran, 24(1), 126-138.

Gunawan, I., dan Benty, D. D. N. 2017. Manajemen Pendidikan: Suatu Pengantar Praktik. Bandung: Alfabeta.

Imron, A. 2004. Manajemen Peserta Didik Berbasis Sekolah. Malang: Departemen Pendidikan Nasional Universitas Negeri Malang.
Mulyasa, E. 2007. Manajemen Berbasis Sekolah. Bandung: Rosdakarya.

Mustiningsih. 2005. Manajemen Layanan Khusus di Lembaga Pendidikan. Universitas Negeri Malang: Fakultas Ilmu Pendidikan.

Rosa, R. E. 2014. Faktor Penghambat Pelaksanaan Praktikum dalam Proses Belajar Biologi Sekolah Menengah Pertama di Kecamatan Kutabaro Kabupaten Aceh Besar. (online), (http://etd.unsyiah.ac.id/index.php? $\mathrm{p}=$ show_ detail\&id=4732), diakses 25 April 2016.

Tim Pakar Manajemen Pendidikan. 2002. Manajemen Pendidikan. Malang: Universitas Negeri Malang.

Wiyono, B. B. 1999. Manajemen Layanan Khusus di Sekolah. Malang: Jurusan Administrasi 